\title{
FEJLESZTÉSI KONCEPCIÓK A KISTÉRSÉGEK SZÁMÁRA
}

\author{
(Regional Development Strategies for Micro-regions)
}

\author{
Az összefoglaló A területi tervezés új kihivása: a területfejlesztési \\ koncepció címủ konferencián (Győr, 1997. április 3-4.) elhangzott \\ III. pódiumbeszélgetések alapján készült.
}

\section{SZÖRÉNYINÉ KUKORELLI IRÉN}

A kistérség a 90-es évektöl kapott új értelmet és tartalmat, és az utóbbi években vált egy olyan szakszóvá, amit a területfejlesztés, a regionális tudományok, a földrajz egyre gyakrabban használ, vagyis a kistérség térkategóriává vált.

A kistérség és a kistérségi szerveződések elkülönülnek egymástól, míg az elöbbi egy térben lehatárolt területet, addig az utóbbi települési önkormányzatok csoportját jelenti, ahol az önkormányzatok többnyire az együttmüködési társulás formáját választották. A valamilyen tudományos, kvázi egzakt módszerekkel lehatárolt kistérségeket és az önkéntes alapon létrejött kistérségi szerveződéseket a kutatók megpróbálták közelíteni, azaz ahol csak lehetett, egy kistérség - egy kistérségi szövetség elvét sugallni. Mindezek mellett megtaláljuk a KSH által lehatárolt kistérségeket, amelyek többnyire nem egyeznek meg az önkiválasztási alapon térré formálódó kistérségi szervezỏdésekkel. Az együttmúködések életre hívása, születésük előmozdítója legtöbbször valamely pályázati lehetőség követelménye. Ezek az okok nyomon követhetők voltak kampányszerü megalakulásuk során. 1996-ban, a területfejlesztési törvény életbe lépésével egy újabb alakulási hullám kezdődött, hogy most már ennek a törvénynek szellemében alakuljanak meg vagy újjá a kistérségek. Tehát azok a települések, amelyek még nem tömörültek kistérségi szövetségbe, hozzanak létre újat, illetve váljanak egy korábban már mủködö szerveződés tagjaivá.

A kistérségek megalakulásának, múködésének lassan egy évtizedes múltja azt bizonyítja, hogy ennek a téregységnek helye van a magyar területfejlesztésben. Ez olyan területi szint, mely magyarországi minta és tapasztalat nélkül formálódott, és a források hiányának ellenére megmaradt. Megmaradását, müködését, kialakult státuszát az alulról építkezésben kell keresni, ereje a helyi döntéshozók tenni akarásával magyarázható.

De vissza kell kanyarodnunk a pódiumbeszélgetés témájához, a kistérségek fejlesztési koncepcióihoz, azok módszertanához. Néhány alapvető kérdést fogalmaztunk meg, amelyekre a pódiumbeszélgetés témáját fel kivánjuk füzni.

- A kistérségi döntéshozók számára megfogalmazódik-e a koncepció hiánya, illetve a koncepció kidolgozását szükségesnek érzik-e, s ha igen, miért?

- Hogyan készülnek ezek a koncepciók?

- Milyen szerepük van a koncepcióknak a kistérségi szövetségek életében?

- Mennyire hasznosak, és miben rejlik hasznosságuk? 
$\mathrm{Az}$ érdemi válaszok érdekében megpróbáltuk ezt a pódiumbeszélgetést úgy megszervezni, hogy mind a létrehozók, mind a koordinálók, mind a koncepciókészitök képviseltessék magukat. Fekete Éva, a Magyar Tudományos Akadémia Regionális Kutatások Központja Észak-magyarországi Osztályának vezetöje létrehozója, koordinátora és koncepció-készítöje a Cserehát Településszövetségnek, tehát tőle több nézőpontból is várhatunk a feltett kérdésekre válaszokat. A koncepció-készítö oldaláról közelíti meg a feltett kérdéseket Dr. Kovács Géza, a BKE egyetemi tanára, elméleti szakember, és Heinrich Péter, a Magyar Vállalkozásfejlesztési Alapítvány székesfehérvári irodájának képviselöje, aki több kistérségfejlesztési koncepciót készitett Fejér megyei kistérségek számára. A kistérségi szerveződések részéröl Gergó András, a Rábcatorok Regionális Fejlesztési Társulás elnöke, és Domina Erzsébet, a Muramenti Nemzetiségi Társulás térségmenedzsere mondják el véleményüket. A koordinátorok részéröl Lengyel Róbert, a Györ-Moson-Sopron megye Területfejlesztési Irodájának fötanácsosának véleményét ismerhettük meg, aki a kistérségek és a megye közötti koordinációt végzi, illetve Körmendi János megyei fỏépítész tapasztalataival találkozhatunk, aki az elkészült koncepciók és a területrendezés, rendezési tervek egymásra épülésének szükségességét hangsúlyozta.

Fekete Éva a kutató és a kistérségi döntéshozó oldaláról is világosan látja a koncepció szükségességét, a kistérség müködése számára nélkülözhetetlen stratégia meglétét. Véleménye szerint, s ezt osztjuk mindannyian, akik koncepciót készitünk, a kistérségi koncepció már a léptéke miatt jelentös különbségeket hordoz a megyére vagy régióra vonatkozó területfejlesztési koncepcióval szemben. A felhasználói és az érintett kör miatt is lényegesen részletesebb kidolgozást igényel, és sokkal inkább a helyi közösségekre támaszkodik. Elsősorban nem a hivatalok, és nem csak az önkormányzatok bevonására kell gondolni, hanem a térségben élö vállalkozóknak, civil szervezeteknek a véleményét is ki kell kérni, be kell építeni, és segítőszándékukat el kell fogadni. De a mai magyar kistérségekben a civil szervezetek száma kevés, vagy hiányoznak. Ezek hiányában a lakosság aktív, tenni kész rétegét kell megszólítani és véleményükre támaszkodni.

A kistérségek döntéshozóiban vajon megfogalmazódik-e a koncepció igénye? Fekete Éva szerint kevés, nagyon kevés az olyan kistérségi szövetség, amely a megalakulás után közvetlenül a koncepció készítését tartja elsődleges szempontnak. Elsősorban azok tartják valóban szükségesnek a koncepciót, akik a közös munkát, társadalmi vagy gazdasági fejlesztést az alakulás után rögtön megkezdik, de hamar rájönnek, hogy ha nincs átgondolt terv, akkor parttalanná válhat a munka, s az akarat is. Ezek a kistérségek vannak kisebbségben. A mai magyar tapasztalatok azt mutatják, a kistérségi társulások azért tartják fontosnak a koncepció elkészíttetését, azért szükséges számukra, mert ezzel pályázni lehet, tehát alapvetően pénzszerzési eszközként fogják fel, vagy csak egyszerüen azért készíttetik el, mert "hát éppen erre adnak pénzt, és ha erre lehet pénzt kapni, akkor ezzel kell foglalkozni". Tehát jelenleg ma Magyarországon még nagyon kevés az olyan kistérség, amely valóban azért rendel meg vagy kezd el készíteni ilyen tervet, mert úgy gondolja, hogy a napi munkájában erre ténylegesen szüksége van. 
De vajon igy látják-e ezt a tényt a konferencián résztvevố kistérségek képviselöi is?

Gergó András, a Rábcatorok Regionális Térségfejlesztési Társulás elnöke azon kevesek közé tartozott, aki már a kistérségi társulás megalakitása elött felkeresték az MTA RKK Nyugat-magyarországi Tudományos Intézetét, hogy az szakértelmével, tanácsaival segitse a megalakuló kistérséget, $\mathrm{s}$ megalakulás után készítse el a térség fejlesztési koncepcióját. A hét polgármester már a kezdetek elött jól látta, hogy összehangolt fejlesztésre van szükség, olyanra, amelynek a föbb pontjait és vázát a társulás döntéshozói csakis közösen fogalmazhatják meg a késöbbi konfliktusok elkerülése miatt, amelyek esetleg a társulás felbomlásához is vezethetnek. Ugyanakkor a szakértôk, a kutatók objektiv tényfeltárása, a koncepció-készités módszertanában való jártasságuk a koncepció megfogalmazásához vezetett úgy, hogy „az elfogult tévutakat nem engedték érvényre juttatni, de engedték kitalálni, hogy mi mit akarunk"- mondta a társulás elnöke, $s$ majd igy folytatta: „az eredmény - azaz a fejlesztés irányai azt tartalmazzák, amit annak idején mi is fontosnak tartottunk, szerettünk volna elérni, de a hogyanjához a mikéntjéhez kellett a szakmai háttér".

Meg kell jegyezni, hogy a legtöbb kistérség akár elkészittette a koncepcióját, akár nem, a müködése kezdetén észlelhette már, hogy nemcsak a különböző pályázatok elnyerésének, de beadásának is az egyik feltétele a térségre vonatkozó koncepció megléte. Ebben a konferencián résztvevő kistérségi tisztségviselök és térségmenedzserek véleménye is megegyezett. Akár a kistérségek belső müködésének eredményessége érdekében, akár külső források megszerzéséért folyó küzdelemben szükséges a koncepciók megléte, mintegy „véres kard”-ként való felmutatása. De vajon hogyan készülnek a koncepciók, pontosabban hogyan készüljenek, ahhoz, hogy testre, azaz az adott kistérségre szabottak legyenek?

Fekete Éva a kistérségi tervezés menetét a koncepció készítés folyamatát ismertette, s hangsúlyozta, hogy az eredményesség érdekében a koncepciót részletesen ki kell bontani, jóval részletesebben, mint egy megyei koncepciót. Csak a koncepcióval még a kistérség nem fog tudni semmit sem kezdeni, a stratégiakészítés után a programok és a projektek kidolgozására is nagy figyelmet kell fordítani, mert csak ezek részletezése esetén válhat használhatóvá a koncepció.

A kistérségi stratégia felépitését a következő szempontok köré csoportosította:

- a szereplök bevonása;

- a földrajzi terület lehatárolása, helyzetelemzése, alapértékek tisztázása;

- fejlesztési hipotézis felállitása;

- SWOT-analízis elkészítése;

- jövőkép megfogalmazása;

- alapstratégia kiválasztása;

- fejlesztési célok és prioritások meghatározása;

- a fô programok meghatározása;

- a feltételrendszer kialakítása. 
„Ahhoz, hogy térségspecifikus legyen a koncepció" - hangsúlyozta - „a helyzetfeltárás és annak objektív értékelése az egyik legfontosabb, de úgy, hogy az alapstratégia kiválasztásához illeszthető tényfeltárást részletekig menỏen kell kidolgozni, az alapértékek felszinre kerülésével". Fontos, hogy a helyzetértékelés piaci szemléletü legyen, hiszen gazdaságfejlesztési stratégiáról van szó.

A tervezés módszertanának alapja a közös tervezési módszer. A csoportmunka a tervezés egész folyamatában szerepet játszik és a szakértö tevékenység bizonyos pontokon avatkozik be a tervezési folyamatba. A helyi szereplökkel való együttmükődés során alapvető a közös gondolkodás, sőt számukra meg kell hagyni azt a lehetöséget, hogy ők döntsenek, ök mondják ki azokat a kérdéseket, esetleg megoldásokat is, melyeket a szakértők meg tudnának fogalmazni, de akkor nem lenne az övék a készülö stratégia.

A következő fontos elemet az építkezés szintjei jelentik. Egy kistérségi koncepciónak, nyilván csak akkor lesz súlya és csak akkor lesz bármi köze a megvalósításához, ha konszenzuson alapul. Ez az egyik fö oka annak, hogy településszintröl kell indítani az épitkezést. Ebben van lényeges különbség a megyei és kistérségi koncepció-készítési folyamatban. A kistérségi szinten sokkal élesebben vetödnek fel bizonyos konfliktusok, hiszen mások a szereplök, akik részt vesznek a program megformálásában.

Nagyon sok hasonló vonást, megközelítést fedezhetünk fel az előzõ vélemény és Kovács Géza koncepciókészitésben szerzett tapasztalataiban. Ő is hangsúlyozza a változatos terek meglétét, $\mathrm{s}$ ezekhez kapcsolódó specifikus kezelési lehetöségek fontosságát. Az általa koordinált Zselici kistérségi koncepcióban törekedett a települési sajátosságok hangsúlyozására, ugyanakkor a felsorolt, megvalósítható programok között fontossági sorrend felállitását nem tette szükségessé. A kistérségi fejlesztések egyik lehetséges, fontos tényezöjeként említi, hogy megfelelö szabályozásokkal a helyben megtermelt jövedelmek nagyobb hányadának helyben maradása esetén nagyobb eséllyel valósulhatnának meg a koncepciókban megfogalmazott programok, hiszen éppen napjaink egyik ellentmondása - ami a kistérségek esetében fokozottan igaz - a területi decentralizáció és a pénzügyi eröforrások decentralizációja közötti disszonancia.

A fentiekben mindkét említett kistérségi koncepció egy-egy fejletlenebb kistérség számára készült, éppen ezért merül fel bennünk a kérdés, vajon milyen eltérésekkel kell számolnunk a fejlettebb és fejletlenebb kistérségekben folyó tervezés során, miben különbözik két eltérö fejlettségü kistérség koncepciója?

Alapvetö különbségnek látszik, hogy a fejlett terulleteken kisebb a belsö motiváltság az összefogás irányába, tehát nagyobb a külső hatás szerepe, ugyanakkor erősebbek a belső konfliktusok, nagyobb a települések közötti rivalizálás. Ezekből a megállapitásokból már következik, hogy a fejlettebb térségekben meghatározó szerep jut a közösségfejlesztésnek, talán sok esetben a konkrét gazdaságfejlesztéssel szemben is. Ellentmondásnak, de mégis valóságnak tünik az a tény, miszerint a fejletlenebb térségben erősebb a fejlettebbekben gyengébb a motiváció, az igény a fejlödést elömozditó tervek, programok iránt, ugyanakkor a humán feltételek, a kreativitás gyengébb a fejletlenebb térségekben, ami a megoldást nehézkesebbé, a külső szakértők munkáját elkerülhetetlenné teszi, annak ellenére, hogy forrásaik szükösebbek. 
Heinrich Péter a Fejér megyei kistérségfejlesztési programok készitése során több példával tudott szolgálni a fejlettebb és fejletlenebb kistérségek koncepcióinak tartalmát, különbözöségeit illetöen. Hangsúlyozta, hogy a program inditásakor, s majd a mühelymunka-megbeszélések során nagyon komoly különbség adódik a különbözō fejlettségũ térségek között, ami abban is meglátszik, hogy már az ötletbörze is sokkal szegényesebb. De alapvetōen különböznek a megvalósitható projektek is. A fejlettebb térségben elōbb lehet a programok megvalósitására vállalkozó szellemü embereket találni, ami nem meglepō, hiszen a befektetés is biztosabban térül meg.

Mindezek ellenére a kistérségi koncepciók módszerében alapvetö különbség nincs. Akár fejlett, akár fejletlenebb a térség, hangsúlyos a szakértōk és a helyi szereplök együttmüködése, a visszacsatolásokon keresztüli folyamatos tervezés megvalósitása. A kistérségi koncepció módszerére vonatkozóan - függetlenül attól, hogy az ország mely részén, milyen munkacsoport késziti - négy alapvetö ismérvet kell kiemelni, ami lényegesen különbözik a nagyobb téregységre készülö fejlesztési stratégiáktól:

- településszintre való építkezés fontossága;

- helyi szereplök folyamatos közremüködése a koncepciókészités során, azaz a közös tervezési módszer;

- a koncepció megfogalmazásán túl a programok részletes kimunkálása;

- a folyamatos társadalmi kontroll.

Csupán két kérdéskör maradt, melyre még nem kaptunk választ. Az egyik: milyen szerepük van a koncepcióknak a kistérségi szövetségek életében? A másik kérdés, hogy mennyire hasznosak, és miben mutatkozik meg a hasznosságuk.

Mindkét kérdésre a gyakorlat oldaláról keressük a választ, mikor a múködő kistérségi szövetségek, illetve a Megyei Önkormányzat képviselöinek véleményét latolgatjuk.

A pódiumbeszélgetés kezdetén megbizonyosodtunk arról, hogy ha a kistérségek koncepciójukat nem belső késztetésre elkészíttetik, akkor külsö kényszer hatására cselekszenek. Felmerül a kérdés, tudják-e használni, használják-e az elkészített tervet. Gergó András így fogalmazott: "A koncepció elkészülte elött egy fehér lap volt elöttünk, ma egy vaskosabb anyag áll rendelkezésünkre, egy olyan anyag, amelyet - mondhatom úgy - Bibliaként forgatunk azért, mert abban az van megfogalmazva, amit annak idején szerettünk volna elérni, és higgyék el, annál biztatóbb, ösztönzöbb mód, eszköz nem szükséges számunkra, mint amikor megismerve a meglévö adottságainkat, engedték kitalálni, hogy mi mit akarunk. Koncepciónk előnye a realitás, a megvalósíthatóság, az iránymutatás. Készitői tiszteletben tartották az önálló döntési jogkörünket, a lehetöségeinket fogalmazták meg, a koncepciót élövé nekünk kell tenni a napi müködésünkkel, a müködésnek tartalommal való megtöltésével."

Domina Erzsébet a Muramenti Nemzetiségi Térségfejlesztési Társulás térségmenedzsere a saját koncepciójuk használhatóságát értékelte, mikor azt mondta: "Mióta a társuláshoz kerültem, azóta kézikönyvként használom. Valóban nagyon jól használható. Az első kötet a térség egészére, a 11 településre együtt mutatja be a helyzetértékelést. A második kötet településenként tartalmazza 
ugyanezt. Én ezt rendkívül fontosnak és nagyon jónak tartom, mert egyrészt van a térség egészére egy átfogó munka, amiből ki lehetett indulni, tehát ami a közös érdekek mentén füzi fel a feladatokat, de ugyanakkor tudja minden település azt is, hogy a saját lehetôségei, anyagi, szellemi eröforrásai tükrében melyek a legfontosabb feladatai. A koncepció mind települési, mind térségi szinten a fö irányokat fogalmazta meg a társulásunk számára, és a társulás ennek alapján kezdett el dolgozni 1994-tôl, s ma is iránymutatóként tudja használni."

Már ez a két vélemény meggyözött mindannyiunkat arról, hogy a kistérségi koncepciók nem csak a kifelé mutogatás céljából iródtak, hanem ha valóban térségspecifikusak, és kimunkálásukban a helyi szereplök is résztvettek, akkor kézikőnyvekként használhatók. Ugyanakkor nagyon fontos, hogy sem a szerzök, illetve a kutató csoport, sem a helyi döntéshozók ne kezeljék a benne leírtakat megváltoztathatatlan dogmaként, mert ebben az esetben a fejlödés dinamikáját tagadják, s a koncepcióban leírtakhoz való görcsös ragaszkodás, ellenkező hatást válthat $\mathrm{ki}$, a koncepció a fejlődés gátjává válhat. A stratégiai irányt kell mutatnia tehát.

A hozzászólók véleményéböl kitünt, hogy nem csak a kistérségek számára fontosak ezek a koncepciók, hanem a területi fejlesztést befolyásolni, vagy koordinálni hivatott szervezeteknek is. Mindez azért, hogy nagyobb területi egységben elhelyezkedö egymás melletti „mozaikok” fejlesztési terveit koordinálni, a megvalósítást figyelemmel kísérni tudják. Jó példa erre a Győr-Moson-Sopron Megyei Önkormányzat, amely a megyei koordinációt a kistérségekhez tagként belépve is gyakorolni tudja. Lengyel Róbert fötanácsos is megerösitette a megyének azt a szerepét, miszerint az egyes kistérségekben folyó fejlesztések megfelelō koordináció hiján egymás ellen hathatnak, példaként úthálózat fejlesztési és turizmus programot említve.

Körmendi János a Györ-Moson-Sopron Megyei Önkormányzat föépítésze mind a megyei, mind a kistérségi koncepciókat területrendezési aspektusból vizsgálta. Véleménye szerint bármely téregységre készült területfejlesztési koncepció alapul kell, hogy szolgáljon a rendezési terveknek. A koncepciókban csak általánosan megfogalmazott terület-felhasználási igények, infrastruktúra-hálózati elemek és táji, tájképi elemek részletes kidolgozása már a rendezési tervek feladata. A koncepciók harmadik alappilléreként emlegette a nyilvánosságot, a koncepció megismertetése érdekében végzett marketing politikát, mely - úgy vélem - részben a szakma felé, részben a helyi társadalom felé fontos lépés, hiszen a koncepció programjainak megvalósítása nem a szük döntéshozó testületen múlik, hanem a koncepciót megismerő és részben azzal egyetértő, vagy azt formálni kívánó széles társadalmi rétegen.

Összefoglalásképpen a kistérségi koncepció használhatóságának néhány momentumát kell kiemelnünk:

- a nagyobb téregység (megyére, régióra) területfejlesztési koncepciójához való illesztés fontosságát;

- a szomszédos kistérségek koncepcióival való egyeztetés, összehangolás;

- módosításának lehetősége, szükségessége, flexibilitása;

- alkalmasságuk a rendezési tervek elökészítésére. 
A pódiumbeszélgetés célja az volt, hogy több irányból, több nézőpontból és különböző fôldrajzi helyszíneken együttmüködő térségekröl kapjunk információt. Az egyes érintett szereplōkön keresztül ismerhettük meg a koncepció-készités elméletét, a koncepció felhasználásának és alkalmasságának lehetőségét, valamint a koncepciók koordinálásának szerepét. A kistérségi stratégiának egyszerre kell megfelelnie a helyi, a térségi szereplök felé, alkalmazkodnia kell a szomszédos kistérségek koncepcióihoz, kapcsolódnia kell a megyei fejlesztési stratégiához, és el kell tudni magát fogadtatnia a felhasználókkal, befektetökkel is. E sok kritériumnak csak akkor tud egyszerre eleget tenni, ha programjai nem megváltoztathatatlanok, hanem az alapstratégiát leszámítva, - mely időt álló kell, hogy legyen, - a részletek rugalmasan kezelhetők. Valóban készültek-e ilyen flexibilis stratégiák azt csak a következő évek gyakorlata fogja megmutatni, így a koncepciók alkalmazhatóságának és idő́llóságának elemzése majd egy következő konferencia témája lehet. 